\title{
Media Persian
}




\section{Books in the series}

Media Persian

Dominic Parviz Brookshaw

Internet Arabic

Mourad Diouri

Media Arabic

2nd edition

Elisabeth Kendall

www.euppublishing.com/series/emev 
- Essential Middle Eastern Vocabularies •

\section{Media Persian}

\section{Dominic Parviz Brookshaw}

Edinburgh University Press 
(C) Dominic Parviz Brookshaw, 2011

Edinburgh University Press Ltd

22 George Square, Edinburgh

www.euppublishing.com

Typeset in Times New Roman and

printed and bound in Great Britain by

CPI Antony Rowe, Chippenham and Eastbourne

A CIP record for this book is available from the British Library

ISBN 9780748641017 (hardback)

ISBN 9780748641000 (paperback)

The right of Dominic Parviz Brookshaw to be identified as author of this work has been asserted in accordance with the Copyright, Designs and Patents Act 1988. 